\title{
Gambaran Peningkatan Angka Kejadian Gangguan Afektif dengan Gejala Psikotik pada Pasien Rawat Inap di RSJ Prof. Dr. HB. Sa'anin Padang pada Tahun 2010 - 2011
}

\author{
Aisyah Fithri Syafwan, Kurniawan Sedjahtera, Asterina
}

\begin{abstract}
Abstrak
Gangguan suasana perasaan (gangguan afektif atau mood) merupakan sekelompok gambaran klinis yang ditandai dengan berkurang atau hilangnya kontrol emosi dan pengendalian diri. Gangguan afektif dapat berupa depresi, manik atau campuran keduanya (bipolar). Pada beberapa pasien gejala-gejalanya dapat disertai dengan ciri psikotik. Penelitian ini bertujuan untuk mengetahui gambaran peningkatan angka kejadian gangguan afektif dengan gejala psikotik pada pasien rawat inap di RSJ Prof. Dr. HB. Sa'anin Padang dari tahun 2010 - 2011. Penelitian ini dilakukan pada bulan Mei 2013 - Agustus 2013. Metode penelitian adalah deskriptif dengan jumlah sampel sebanyak 199 orang pada tahun 2010 dan 205 orang pada tahun 2011. Data dikumpulkan melalui bagian rekam medik RSJ Prof. Dr. HB. Sa'anin Padang dan hasil yang didapat disajikan dalam bentuk tabel distribusi frekuensi. Hasil penelitian ini menunjukkan bahwa terdapat peningkatan jumlah pasien gangguan afektif dengan gejala psikotik pada pasien rawat inap dari segi umur, jenis kelamin, pasien dari kota Padang dan luar kota Padang. Total pasien rawat inap gangguan afektif dengan gejala psikotik terhadap seluruh pasien rawat inap di RSJ Prof. Dr. HB. Sa'anin Padang adalah 31,7\% (2010) dan 30\% (2011) dengan usia terbanyak 20-29 tahun dan laki-laki lebih banyak daripada perempuan. Status perkawinan ditemukan kasus terbanyak pada pasien yang belum menikah dan berasal dari luar kota Padang, pekerjaan terbanyak ditemukan pada pasien yang tidak bekerja, dari segi pendidikan kasus terbanyak adalah pada SLTA-sederajat.
\end{abstract}

Kata kunci: gangguan manik, gejala psikotik, gangguan depresi berat, gangguan afektif tipe campuran

\begin{abstract}
Affective disorder (mood disorder) is group of clinical picture is characterized by reduced or loss of emotional control and self-control. Affective disorders may include depression, manic or mixture of both. In some patients the symptoms may be accompanied by psychotic featured. This study aims to describe the increase in the incidence of affective disorder with psychotic symptoms in patients hospitalized RSJ Prof. Dr. HB. Sa'anin Padang of the year $2010-$ 2011. This study was conducted in May 2013-August 2013. The research method was descriptive with sample of 199 people in 2010 and 205 people in 2011. Data were collected through medical record section RSJ Prof. Dr. HB. Sa'anin Padang and the results are presented in the form of a frequency distribution table. Results of this study indicate that there are an increasing number of affective disorder with psychotic symptoms in hospitalized patients in terms of age, gender, patients from outside the city of Padang and Padang. Total patients affective disorder with psychotic symptoms in patients hospitalized RSJ Prof. Dr. HB. Sa'anin Padang was 31.7\% (2010) and 30\% (2011) to the age of 20-29 years and the majority of men more than women. Married status of cases found in patients who have not been married and come from outside the city of Padang, most jobs are found in patients who do not work, in terms of education most cases is the high school-equivalent.
\end{abstract}

Keywords:manic disorder, psychotic symptoms, major depressive disorder, affective disorder mixed type

Affiliasi penulis : Fakultas Kedokteran Universitas Andalas Korespondensi: Aisyah Fithri Safwan, email: aisyahfithri24@yahoo.com, Telp: 085274097772

\section{PENDAHULUAN}

Gangguan suasana perasaan (gangguan afektif atau mood) merupakan sekelompok gambaran klinis yang ditandai dengan berkurang atau hilangnya kontrol emosi dan pengendalian diri. Perubahan afek ini biasanya disertai dengan suatu perubahan pada keseluruhan tingkat aktivitas kehidupan dan kebanyakan gejala lainnya adalah sekunder terhadap perubahan itu, atau mudah dipahami hubungannya dengan perubahan tersebut. ${ }^{1}$ Gangguan afektif dapat berupa depresi, manik atau campuran keduanya (bipolar). Pada beberapa pasien gejala-gejalanya dapat disertai dengan ciri psikotik. ${ }^{2}$
Depresi telah dicatat sejak masa lampau dan semakin meningkat dengan makin banyaknya tuntunan zaman. Gangguan depresif adalah salah satu jenis gangguan jiwa yang sering terjadi. Prevalensi gangguan depresi pada populasi dunia adalah $3-8 \%$ dengan 50 kasus yang terjadi pada usia produktif yaitu 20-50 tahun. World Health Organization menyatakan bahwa gangguan depresif berada pada urutan keempat penyakit di dunia. Gangguan depresif mengenai sekitar $20 \%$ wanita dan $12 \%$ laki-laki pada suatu waktu dalam kehidupan. Pada tahun 2020 diperkirakan jumlah gangguan depresif semakin meningkat dan akan menempati urutan kedua penyakit didunia. ${ }^{3} \mathrm{Di}$ Amerika Serikat, di kalangan karyawan kantor $44 \%$ mengalami stres dengan menunjukkan perubahan emosi dan perilaku dikarenakan beban pekerjaan yang terlalu berat 
sementara waktu yang tersedia sangat sempit. ${ }^{4}$ Insidensi gangguan depresi berat juga lebih tinggi pada pasien perawatan primer, yang mendekati $10 \%$, dan pada pasien rawat inap yang mendekati $15 \%$. Gangguan bipolar adalah gangguan yang lebih jarang daripada gangguan depresif berat, dengan prevalensi seumur hidup $2 \%$, sama dengan angka untuk skizofrenia. Pada umumnya gangguan depresif berat terjadi paling sering pada orang yang tidak memiliki hubungan interpersonal yang erat, bercerai atau berpisah. Gangguan bipolar lebih sering pada orang yang bercerai dan hidup sendirian daripada orang yang menikah ${ }^{5}$. Episode manik lebih sering pada lakilaki, dan episode depresif lebih sering pada wanita. Gejala manik pada remaja temasuk dalam psikotik, alkohol atau penyalahgunaan zat lainnya, usaha bunuh diri, masalah akademik, beberapa keluhan somatik, dan perilaku anti sosial lainnya. Meskipun gejala-gejala ini terlihat pada remaja yang normal, gejala yang parah atau terus-menerus harus menjadi pertimbangan dokter untuk penatalaksanaan. ${ }^{6}$

Gangguan afektif pada anak-anak dan remaja telah dikenali dan diperhatikan selama beberapa dekade terakhir. Selama banyak generasi, kesedihan dan keputusasaan telah diketahui terjadi pada anak-anak dan remaja, tetapi konsep tentang gangguan afektif memerlukan waktu yang cukup lama untuk diterima secara umum. Suatu kriteria gangguan afektif pada masa anak-anak dan remaja adalah suatu kekacauan mood, seperti depresi dan elasi. Disamping itu iritabilitas dapat merupakan tanda suatu gangguan afektif pada anak-anak atau remaja.

Hasil penelitian Departemen Kesehatan dan Universitas Indonesia di Jawa Barat (2002) menemukan $36 \%$ pasien yang berobat ke puskesmas mengalami gangguan kesehatan jiwa. Hal ini bisa mewakili kondisi masyarakat secara umum. Gangguan yang umum terjadi adalah gangguan afektif atau gangguan mood, yaitu kecemasan, depresi dan manik.

Rumah Sakit Jiwa Prof. Dr. HB. Sa'anin Padang merupakan rumah sakit khusus tipe $A$ yang dikelola oleh pemerintah Propinsi Sumatera Barat. Rumah sakit tersebut memberikan pelayanan promotif, preventif, kuratif, dan rehabilitatif serta menjadi pusat rujukan dan tempat penelitian dalam pengembangan ilmu dan teknologi kesehatan. Mutu layanan kesehatan berorientasi pada pelanggan internal yaitu tenaga medis, paramedis, non medis, dan tenaga fungsional lainnya serta pelanggan eksternal yaitu pasien, keluarga pasien dan pihak yang berkepentingan lainnya.

Menurut data dari Rekam Medik RSJ Prof. Dr. HB. Sa'anin Padang, pasien rawat inap terjadi peningkatan dari tahun 2009 sampai tahun 2011, pada tahun 2009 berjumlah 1004 orang, pada tahun 2010 berjumlah 1259 orang, dan pada tahun 2011 berjumlah 1400 orang, sedangkan pasien rawat inap dengan gangguan afektif dengan gejala psikotik pada tahun 2009 berjumlah 259 orang, pada tahun 2010 berjumlah 399 orang, dan pada tahun 2011 berjumlah 419 orang.

Berdasarkan permasalahan yang telah diuraikan diatas, peneliti merasa tertarik untuk melakukan penelitian tentang "Gambaran Peningkatan Angka Kejadian Gangguan Afektif dengan Gejala Psikotik Pada Pasien Rawat Inap di RSJ Prof. Dr. HB.
Sa'anin Padang Pada Tahun 2010-2011".

Penelitian ini bertujuan untuk mengetahui gambaran peningkatan angka kejadian gangguan afektif dengan gejala psikotik pada pasien rawat inap di RSJ Prof. Dr. HB. Sa'anin Padang dari tahun 20102011.

\section{METODE}

Penelitian ini dilakukan dengan desain penelitian deskriptif di Rumah Sakit Jiwa Prof. Dr. HB. Sa'anin Padang dari bulan Mei 2013 sampai dengan bulan Agustus 2013. Populasi penelitian ini adalah seluruh pasien rawat inap dengan diagnosa gangguan afektif dengan gejala psikotik yaitu sebanyak 399 orang (2010) dan 419 orang (2011) dengan jumlah sampel 199 orang (2010) dan 205 orang (2011).

Langkah pengolahan data yaitu dari semua arsip rekam medik yang terkumpul di identifikasi dan dipisahkan rekam medik status pasien rawat inap gangguan afektif dengan gejala psikotik. Lalu dijumlahkan dan dibuat persentase kasusnya terhadap keseluruhan kasus pada tahun 2010 - 2011 dan dibuat pembagiannya berdasarkan umur, jenis kelamin, status perkawinan, daerah asal, pekerjaan, dan pendidikan.

\section{HASIL}

Telah dilakukan penelitian terhadap pasien rawat inap di RSJ Prof. Dr. HB. Sa'anin Padang pada tahun 2010-2011. Dari sebanyak 1259 orang pasien rawat inap di RSJ Prof. Dr. HB. Sa'anin Padang pada tahun 2010, didapatkan sebanyak 399 orang pasien dengan gangguan afektif dengan gejala psikotik atau $31,7 \%$ dari keseluruhan jumlah pasien rawat inap di RSJ Prof. Dr. HB. Sa'anin Padang pada tahun 2010, dan dari sebanyak 1400 orang pasien rawat inap RSJ Prof. Dr. HB. Sa'anin Padang pada tahun 2011 didapatkan sebanyak 419 orang pasien gangguan afektif dengan gejala psikotik atau 30\% dari keseluruhan jumlah pasien rawat inap di RSJ Prof. Dr. HB. Sa'anin Padang pada tahun 2011.

Tabel 1. Distribusi Frekuensi Pasien Rawat Inap Gangguan Afektif dengan Gejala Psikotik Tahun 20102011 Berdasarkan Umur

\begin{tabular}{ccccc}
\hline \multirow{2}{*}{ Umur } & \multicolumn{2}{c}{$\mathbf{2 0 1 0}$} & \multicolumn{2}{c}{$\mathbf{2 0 1 1}$} \\
\cline { 2 - 5 } & $\mathbf{f}$ & $\%$ & $\mathbf{f}$ & $\%$ \\
\hline$<20$ tahun & 9 & 4,5 & 12 & 5,9 \\
\hline $20-29$ tahun & 84 & 42,2 & 75 & 36,6 \\
$30-39$ tahun & 60 & 30,2 & 68 & 33,2 \\
$40-49$ tahun & 31 & 15,6 & 32 & 15,6 \\
$50-60$ tahun & 15 & 7,5 & 16 & 7,8 \\
$>60$ tahun & 0 & 0 & 2 & 1 \\
\hline Total & 199 & 100 & 205 & 100 \\
\hline
\end{tabular}

Berdasarkan tabel 1 didapatkan umur penderita gangguan afektif dengan gejala psikotik yang dirawat inap pada tahun 2010-2011 terbanyak adalah pada usia 20 - 29 tahun yaitu sebanyak $42,2 \%$ pada tahun 2010 dan $36,6 \%$ pada tahun. Sedangkan untuk persentase yang terendah ditemukan pada usia $>60$ tahun yaitu sebanyak $0 \%$ pada tahun 2010 dan $2 \%$ pada tahun 2011 . Hasil penelitian ini secara umum menunjukkan adanya peningkatan persentase pasien gangguan afektif dengan psikotik dari tahun 2010 ke tahun 2011, kecuali pada usia 20 - 29 tahun. 
Tabel 2. Frekuensi Pasien Rawat Inap Gangguan Afektif dengan Gejala Psikotik Tahun 2010-2011 Berdasarkan Jenis Kelamin

\begin{tabular}{ccccc}
\hline \multirow{2}{*}{$\begin{array}{c}\text { Jenis } \\
\text { Kelamin }\end{array}$} & \multicolumn{2}{c}{$\mathbf{2 0 1 0}$} & \multicolumn{2}{c}{$\mathbf{2 0 1 1}$} \\
\cline { 2 - 5 } & $\mathbf{f}$ & $\%$ & $\mathbf{f}$ & $\%$ \\
\hline Laki-laki & 150 & 75,4 & 151 & 73,7 \\
Perempuan & 49 & 24,6 & 54 & 26,3 \\
\hline Total & 199 & 100 & 205 & 100 \\
\hline
\end{tabular}

Berdasarkan tabel 2 didapatkan jenis kelamin penderita gangguan afektif dengan gejala psikotik yang dirawat inap pada tahun 2010 terbanyak adalah laki-laki yaitu sebanyak 75,4 dan $73,7 \%$ pada tahun 2011, sedangkan untuk wanita hanya sebanyak $24,6 \%$ pada tahun 2010 dan $26 \%$ pada tahun 2011 . Hasil penelitian pada jenis kelamin gangguan afektif dengan gejala psikotik menunjukkan peningkatan pada laki-laki maupun perempuan pada tahun 2011 dibandingkan tahun 2010.

Tabel 3. Distribusi Frekuensi Pasien Rawat Inap Gangguan Afektif dengan Gejala Psikotik Tahun 20102011 Berdasarkan Status Perkawinan

\begin{tabular}{ccccc}
\hline Status Perkawinan & \multicolumn{2}{c}{$\mathbf{2 0 1 0}$} & \multicolumn{2}{c}{$\mathbf{2 0 1 1}$} \\
\cline { 2 - 5 } & $\mathbf{f}$ & $\%$ & $\mathbf{f}$ & $\%$ \\
\hline Belum Menikah & 117 & 58,8 & 112 & 54,6 \\
Sudah Menikah & 77 & 38,7 & 87 & 42,4 \\
Bercerai & 5 & 2,5 & 6 & 2,8 \\
\hline Total & 199 & 100 & 205 & 100 \\
\hline
\end{tabular}

Berdasarkan tabel 3 didapatkan status perkawinan penderita gangguan afektif dengan gejala psikotik yang dirawat inap pada tahun 2010-2011 terbanyak adalah pada pasien yang belum menikah yaitu sebanyak $58,8 \%$ pada tahun 2010 dan $54,6 \%$ pada tahun 2011, sedangkan frekuensi terendah pada pasien yang bercerai yaitu sebanyak $2,5 \%$ pada tahun 2010 dan $2,8 \%$ pada tahun 2011. Hasil penelitian ini secara umum menunjukan bahwa terjadi peningkatan jumlah pasien rawat inap gangguan afektif dengan gejala psikotik pada tahun 2010-2011 menurut status perkawinan, kecuali pada pasien yang belum menikah.

Tabel 4. Distribusi Frekuensi Pasien Rawat Inap Gangguan Afektif dengan Gejala Psikotik Tahun 2010 2011 Berdasarkan Daerah Asal

\begin{tabular}{ccccc}
\hline Daerah Asal & \multicolumn{2}{c}{$\mathbf{2 0 1 0}$} & \multicolumn{2}{c}{$\mathbf{2 0 1 1}$} \\
\cline { 2 - 5 } & $\mathbf{f}$ & $\%$ & $\mathbf{f}$ & $\%$ \\
\hline Kota Padang & 63 & 31,7 & 69 & 33,7 \\
\hline Luar Kota Pdg & 136 & 68,3 & 136 & 66,3 \\
\hline Total & 199 & 100 & 205 & 100 \\
\hline
\end{tabular}

Berdasarkan tabel 4 distribusi frekuensi daerah asal penderita gangguan afektif dengan gejala psikotik yang dirawat inap pada tahun 2010-2011 terbanyak adalah pasien yang berasal dari luar kota Padang yaitu sebanyak $68,3 \%$ pada tahun 2010 dan $66,3 \%$ pada tahun 2011 , sedangkan untuk pasien yang berasal dari kota Padang sebanyak $31,7 \%$ pada tahun 2010 dan 33,7\% pada tahun 2011. Hasil penelitian ini menunjukkan peningkatan pasien rawat inap yang berasal dari kota Padang dan frekuensi tetap untuk pasien yang berasal dari luar kota Padang pada tahun $2010-2011$.
Tabel 5. Distribusi Frekuensi Pasien Rawat Inap Gangguan Afektif dengan Gejala Psikotik Tahun 20102011 Berdasarkan Pekerjaan

\begin{tabular}{lcccc}
\hline \multicolumn{1}{c}{ Pekerjaan } & \multicolumn{2}{c}{$\mathbf{2 0 1 0}$} & \multicolumn{2}{c}{$\mathbf{2 0 1 1}$} \\
\cline { 2 - 5 } & $\mathbf{f}$ & $\%$ & $\mathbf{f}$ & $\%$ \\
\hline PNS & 3 & 1,5 & 7 & 3,4 \\
Petani & 9 & 4,5 & 6 & 2,9 \\
Wiraswasta & 2 & 1,0 & 2 & 1,0 \\
Mahasiswa & 5 & 2,5 & 0 & 0 \\
Pelajar & 0 & 0 & 4 & 2,0 \\
Ibu RumahTangga & 19 & 9,5 & 30 & 14,6 \\
Tidak Bekerja & 161 & 80,9 & 156 & 76,1 \\
\hline \multicolumn{1}{c}{ Total } & 199 & 100 & 205 & 100 \\
\hline \multicolumn{2}{c}{}
\end{tabular}

Bedasarkan tabel 5 didapatkan pekerjaan penderita gangguan afektif dengan gejala psikotik yang dirawat inap pada tahun 2010-2011 yang terbanyak adalah pada pasien yang tidak bekerja yaitu sebanyak $80,9 \%$ pada tahun 2010 dan $76,1 \%$ pada tahun 2011, sedangkan untuk persentase yang terendah ditemukan pada pelajar yaitu sebanyak $0 \%$ pada tahun 2010 dan $2 \%$ pada tahun 2011. Hasil penelitian ini menunjukkan peningkatan distribusi frekuensi pada PNS, pelajar dan ibu rumah tangga. Sedangkan menunjukkan penurunan distribusi frekuensi pada petani, mahasiswa dan pasien yang tidak bekerja.

Tabel 6. Frekuensi Pasien Rawat Inap Gangguan Afektif dengan Gejala Psikotik Tahun 2010-2011 Berdasarkan Pendidikan

\begin{tabular}{lcccc}
\hline \multirow{2}{*}{ Pendidikan } & \multicolumn{2}{c}{$\mathbf{2 0 1 0}$} & \multicolumn{2}{c}{$\mathbf{2 0 1 1}$} \\
\cline { 2 - 5 } & $\mathbf{f}$ & $\mathbf{\%}$ & $\mathbf{f}$ & $\%$ \\
\hline Sarjana (S1) & 20 & 10,1 & 18 & 8,8 \\
D3 & 3 & 1,5 & 6 & 2,9 \\
SLTA-sederajat & 86 & 43,2 & 85 & 41,5 \\
SLTP-sederajat & 36 & 18,1 & 43 & 21,0 \\
SD & 52 & 26,1 & 45 & 22,0 \\
Tidak sekolah & 2 & 1,0 & 8 & 3,8 \\
\hline \multicolumn{1}{c}{ Total } & 199 & 100 & 205 & 100 \\
\hline
\end{tabular}

Berdasarkan tabel 6 didapatkan pendidikan penderita gangguan afektif dengan gejala psikotik yang dirawat inap pada tahun 2010-2011 terbanyak adalah pada SLTA - sederajat yaitu sebanyak $43,2 \%$ pada tahun 2010 dan $41,5 \%$ pada tahun 2011, sedangkan terendah adalah pada pasien yang tidak sekolah yaitu sebanyak $1 \%$ pada tahun 2010 dan $3,8 \%$ pada tahun 2011. Hasil penelitian ini menunjukan bahwa adanya peningkatan pada D3, SLTP - sederajat dan pasien yang tidak sekolah. Sedangkan menunjukkan penurunan pada pasien sarjana (S1), SLTA - sederajat dan SD.

\section{PEMBAHASAN}

Dari hasil penelitian ini didapatkan usia terbanyak pada pasien rawat inap di RSJ Prof. Dr. HB. Sa'anin Padang pada tahun 2010-2011 adalah usia 20 - 29 tahun yaitu sebanyak $42,2 \%$ pada tahun 2010 dan $36,6 \%$ pada tahun 2011 . Kemudian usia nomor dua terbanyak setelah itu adalah 30 - 39 tahun yaitu sebanyak $30,2 \%$ pada tahun 2010 dan $33,2 \%$ pada tahun 2011. Untuk usia nomor tiga terbanyak adalah 40 - 49 tahun yaitu sebanyak $15,6 \%$ pada tahun 2010 dan 2011. Penelitian ini sesuai dengan prevalensi gangguan depresi pada populasi dunia terbanyak pada usia produktif yaitu $20-50$ tahun. ${ }^{5}$ Hasil 
penelitian Wening dkk padatahun2010, didapatkan usia terbanyak adalah $16-24$ tahun $(58,6 \%)$. Alasan perbedaan telah diteliti melibatkan perbedaan hormonal, perbedaan stressor psikososial dalam rentang umur tersebut. Secara keseluruhan jumlah pasien meningkat dari tahun 2010 - 2011.

Hasil penelitian tentang jenis kelamin pada penelitian ini didapatkan prevalensi laki-laki lebih besar daripada wanita yaitu sebanyak 75,4\% (2010) dan $73,7 \%$ (2011), namun secara umum kasus depresi prevalensinya lebih tinggi pada wanita. Menurut Kaplan dan Shadock yaitu $20 \%$ pada wanita dan $12 \%$ pada laki-laki. Penelitian Wening dkk (2010) didapatkan prevalensi pasien gangguan depresi di RSUD Banyumas sekitar $62,1 \%$ pada wanita dan $37,9 \%$ pada laki-laki. ${ }^{9}$ Hasil penelitian ini berbeda karena pada penelitian ini sampel adalah rawat inap. Alasan adanya perbedaan tersebut tidak diketahui. Penelitian telah jelas menunjukkan bahwa perbedaan didalam masyarakat Barat tidak semata-mata karena praktik diagnostik yang secara sosial mengalami bias. Alasan perbedaan telah diteliti melibatkan perbedaan hormonal, perbedaan stressor psikososial bagi laki-laki dan perempuan. ${ }^{5}$

Prevalensi penelitian pada status perkawinan terbanyak didapatkan pada pasien rawat inap yang belum menikah yaitu sebanyak $58,8 \%$ pada tahun 2010 dan $54,6 \%$ pada tahun 2011, sedangkan frekuensi terendah ditemukan pada pasien yang bercerai yaitu sebanyak 2,5\% pada tahun 2010 dan $2,8 \%$ pada tahun 2011. Hasil ini sesuai dengan penelitian Wening dkk (2010) didapatkan yang terbanyak adalah pada yang belum menikah $(62,1 \%)$. Menurut Kaplan dan Shadock depresi banyak ditemukan pada orang hidup sendiri/belum menikah. Secara keseluruhan terjadi peningkatan pasien rawat inap gangguan afektif dengan gejala psikotik pada tahun 2010-2011 menurut status perkawinan, kecuali pada pasien yang belum menikah.

Sebanyak 68,3\% pada tahun 2010 dan $66,3 \%$ pada tahun 2011 pasien rawat inap berasal dari luar kota Padang, sedangkan hanya $31,7 \%$ pada tahun 2010 dan 33,7\% pada tahun 2011 yang berasal dari kota Padang.

Hasil penelitian mengenai pekerjaan pasien rawat inap RSJ Prof. HB. Sa'anin Padang didapatkan yang terbanyak adalah pasien yang tidak bekerja yaitu sebanyak $80,9 \%$ pada tahun 2010 dan $76,1 \%$ pada tahun 2011. Hasil ini sesuai dengan Kaplan dan Shadock bahwa kasus depresi lebih sering ditemukan pada orang-orang yang kehilangan pekerjaan atau pengangguran.

Menurut hasil penelitian mengena pendidikan pasien rawat inap RSJ Prof. HB. Sa'anin Padang didapatkan yang terbanyak adalah pada SLTA - sederajat yaitu sebanyak $43,2 \%$ pada tahun 2010 dan $41,5 \%$ pada tahun 2011 , sedangkan terendah adalah pada pasien yang tidak sekolah yaitu sebanyak $1 \%$ pada tahun 2010 dan $3,8 \%$ pada tahun 2011. Hasil ini berbeda dengan penelitian Wening dkk (2010) didapatkan yang terbanyak adalah tingkat SMP $(41,4 \%)$.

\section{KESIMPULAN}

1. Berdasarkan umur kasus gangguan afektif dengan gejala psikotik terbanyak adalah pada umur 20-29 tahun. Secara keseluruhan terjadi peningkatan terhadap jumlah pasien rawat inap gangguan afektif dengan gejala psikotik pada tahun 2010-2011 kecuali umur 20 -29 tahun.

2. Jenis kelamin terbanyak pada penelitian ini adalah laki-laki. Terjadi peningkatan gangguan afektif dengan gejala psikotik pada pasien rawat inap menurut jenis kelamin baik pada laki-laki maupun perempuan.

3. Status perkawinan terbanyak pada penelitian ini adalah pasien yang belum menikah. Secara keseluruhan terjadi peningkatan terhadap jumlah pasien rawat inap gangguan afektif dengan gejala psikotik menurut status perkawinan kecuali pada pasien yang belum menikah.

4. Daerah asal terbanyak pada penelitian ini adalah pasien yang berasal dari luar kota Padang. Pada data ini terjadi peningkatan terhadap pasien rawat inap yang berasal dari kota Padang.

5. Berdasarkan status pekerjaan, hasil terbanyak pada penelitian ini adalah pasien yang tidak bekerja. Penelitian ini menunjukkan adanya peningkatan distribusi frekuensi kasus pada PNS, pelajar dan ibu rumah tangga. Sedangkan penurunan distribusi frekuensi ditemukan pada petani, mahasiswa dan pasien yang tidak bekerja.

6. Pendidikan terbanyak pada penelitian ini adalah SLTA - sederajat. Hasil penelitian ini menunjukan bahwa adanya peningkatan pada D3, SLTP - sederajat dan pasien yang tidak sekolah. Sedangkan menunjukkan penurunan pada pasien sarjana (S1), SLTA sederajat dan SD.

\section{DAFTAR PUSTAKA}

1. Departemen Kesehatan Republik Indonesia. Pedoman penggolongan dan diagnosis gangguan jiwa di Indonesia III.1996.

2. Amir N. Depresi, aspek neurobiologi diagnosis dan tatalaksana. Jakarta: Balai Penerbit Fakultas Kedokteran Indonesia; 2005.

3. Departemen Kesehatan Republik Indonesia. Pharmaceutical care untuk penderita gangguan depresif. 2007.

4. Hawari D. Manajemen stres, cemas dan depresi. Jakarta: Fakultas Kedokteran Universitas Indonesia; 2001.

5. Wiguna IM. Sinopsis psikiatri jilid 2 . Tangerang: Binarupa Aksara Publisher; 2010.

6. Kaplan HI, Saddock BJ. Synopsis of psychiatric. Edisi ke-9. Lippincott Williams and Wilkins; 2003.

7. Wiguna IM. Sinopsis psikiatri jilid 1. Tangerang: Binarupa Aksara Publisher; 2010.

8. Ikatan Dokter Indonesia Cabang Jakarta Barat. Penting: deteksi dini pada gangguan jiwa; 2007.

9. Wening MA, Made S. Tulus S. Pengaruh terapi kognitif restrukturisasi terhadap penurunan skor depresi pada pasien gangguan jiwa. The Soedirman Journal of Nursing. 2010; 5(3). 